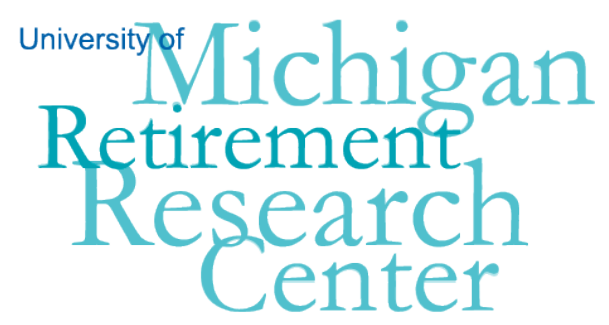

Working Paper

WP 2012-282

\title{
At the Corner of Main and Wall Street: Family Pension Responses to Liquidity Change and Perceived Returns
}

\author{
Thomas Bridges and Frank P. Stafford
}

\begin{tabular}{l|l}
\hline $\mathrm{M}$ & $\mathrm{R}$ \\
\hline $\mathrm{R}$ & $\mathrm{C}$ \\
\hline
\end{tabular}

Project \#: UM11-Q2B 



\title{
At the Corner of Main and Wall Street: Family Pension Responses to Liquidity Change and Perceived Returns
}

\author{
Thomas Bridges \\ University of Michigan \\ Frank P. Stafford \\ University of Michigan \\ December 2012 \\ Michigan Retirement Research Center \\ University of Michigan \\ P.O. Box 1248 \\ Ann Arbor, MI 48104 \\ www.mrrc.isr.umich.edu \\ (734) 615-0422
}

\section{Acknowledgements}

This work was supported by a grant from the Social Security Administration through the Michigan Retirement Research Center (Grant \# 5 RRC08098401-03-00). The study used the Panel Study of Income Dynamics public-use dataset, produced and distributed by the Institute for Social Research, Survey Research Center, University of Michigan, Ann Arbor, MI (2009). The findings and conclusions expressed are solely those of the author and do not represent the views of the Social Security Administration, any agency of the Federal government, or the Michigan Retirement Research Center.

Regents of the University of Michigan

Mark J. Bernstein, Ann Arbor; Julia Donovan Darlow, Ann Arbor; Laurence B. Deitch, Bloomfield Hills; Shauna Ryder Diggs, Grosse Pointe; Denise Ilitch, Bingham Farms; Andrea Fischer Newman, Ann Arbor; Andrew C.

Richner, Grosse Pointe Park; Katherine E. White, Ann Arbor; Mary Sue Coleman, ex officio 


\title{
At the Corner of Main and Wall Street: Family Pension Responses to Liquidity Change and Perceived Returns
}

\begin{abstract}
The U. S. economy experienced a shift away from employment with coverage under a defined benefit (DB) pension plan during 1991-2009. Defined contribution (DC) plan coverage seems not to have risen much, if at all, for married men in the recent decade. Overall, the percent of the labor force covered by any pension type fell over the period 2001-2009, with most of the shift occurring in 2001-2003, as indicated by data from the Panel Study of Income Dynamics (PSID). We seek to determine the factors that lead families to lose or gain DC coverage and to put money into their private pensions or to draw money out of private pensions and annuities prior to age 65. The importance of such discretionary participation and savings responses is accentuated by both the presence of DC pensions, and, presumably, learning that such pensions can be used to stabilize finances prior to retirement. Besides the impact of the overall economic climate, individual, family level events and cash flow changes are expected to play a role in the decision to add to or withdraw from a DC pension plan. Preliminary studies suggest that the savings response by households to recent economic uncertainties during 2009-2011, was greater overall savings and an increase in liquid asset holding, a result consistent with classic predictions of a response to economic turmoil. Overall, pension fund inflows have not been a part of the increase in private saving in the Great Recession.
\end{abstract}

\section{Citation}

Bridges, Thomas, and Frank P. Stafford (2012). "At the Corner of Main and Wall Street:

Family Pension Responses to Liquidity Change and Perceived Returns." University of Michigan Retirement Research Center (MRRC) Working Paper, WP 2012-282.

http://www.mrrc.isr.umich.edu/publications/papers/pdf/wp282.pdf 


\section{Introduction}

Many factors play a role in participating in a (DC) pension and making contributions or drawing money out prior to retirement. In this paper, we study these decisions with balanced two-year panels of married men age 25-62 (at year $t$, rising to approximately age 27-64 at year t+2)) from the Panel Study of Income Dynamics (PSID), 1999 - 2009. Over this same decade there were major changes in the extent and nature of pension coverage of those who were active in the labor force (Ghilharducci, et. al. 2012). While in 1999-2001, 55.3 percent of married men in the PSID age 25-62 who were in the labor force had pension coverage, by 2007-2009 this had fallen to 50.1 percent. $^{1}$ The share of married men with DB pensions fell, and a rising share of those men not in the labor force led to reduced overall pension coverage. Of those with a pension, we observe reduced dollar inflows prior to traditional retirement ages in recessionary periods. ${ }^{2}$

Do pensions lead to increased overall savings? There is some evidence to suggest that they do (Poterba, Venti and Wise, 1996), but here we look at the question of the pensions as a pre-retirement component of net worth to assess the factors leading to increased or reduced pension savings. Which families save or dissave from their pension reserves as they experience changes in cash flow from current income or experience adverse life events? That is, in the context of changing pension status patterns, were there active uses of pension funds as a mid-term financial asset, with funds being managed to meet pre-retirement needs or discretionary expenditures?

Based on analysis of Health and Retirement Study (HRS) data, one factor inducing cashing in of both DC and DB pensions is job change (Hurd, Lillard and

\footnotetext{
${ }^{1}$ These percentages reflect those in the labor market. Substantially because of labor market exits in the 2009 recession the percent of all married men age 25-63 without a pension rose to 57.5 percent in 2007-2009 compared to 50.4 percent in 1999-2001.

${ }^{2}$ Research indicates that employees with company owned stock plans respond positively to rising stock prices as 'momentum' investors (Choi, et al., 2004; Bernartzi, 2001). These studies also identify the response of reallocation out of the company held shares.
} 
Panis, 1998). Those with less education, not having health insurance, and with a shorter remaining life expectancy were shown to be opting to cash in rather than leaving the funds to accumulate. Here we include some of these types of measures but also look at the impact of the shorter run financial circumstances of the family and at earlier points in the life course. In this perspective, pension allocation, notably for DC pensions, is fungible with and a part of overall net worth management and is part of lifetime decisions to save or not to save and to dissave.

Job transitions present opportunities for decisions on the acquisition and disposition of pension balances, particularly for DC plans. With DC pensions, even with no job change, money can be withdrawn prior to retirement and families can decide to put in more money than normal. Using pensions to deal with midlife course spending shocks or income declines or better than normal cash flow from employment was likely becoming more important in the last decade. How widespread is such use of pensions? And did coverage transitions contribute to greater transactional use of DC pensions? Our panel analysis shows that in successive two year balanced panels there were substantial pension status transitions. Undoubtedly, some of this change in type of coverage arises from reporting error (Gustman and Steinmeier, 1999), ${ }^{3}$ though whether covered and whether in the labor force are less likely to be reported with error.

One factor impacting pension participation and management has been changes arising in the housing market. The U.S. economy experienced a dramatic rise in the price of owner occupied housing, 1999-2007, and then a precipitous decline, 20072009. As the U.S. economy experienced this contraction, 2007-2009, along with the sharp drop in the stock market after September 11, 2001, how did families respond? Mortgage distress as of 2009 was induced by holding a risky position in housing as of

${ }^{3} \mathrm{~A}$ recent and more complete assessment of pension reporting issues finds that compared to survey reports (SIPP, 2004), W-2 tax records indicate a participation rate that is about 11 percent higher (Dushi and lams, 2010). The authors indicate that there could also be errors in the $W-2$ reports. PSID respondents also report having both a DC and a DB (See Table 2). 
2007. This over commitment to housing was a factor leading to subsequent pension withdrawals based on a cash flow crisis, and likely not so much on anticipation of poor future returns.

Mortgage payment difficulties were also concentrated in selected real estate markets where homeowners were allocating a substantial share of their income to debt service and other home related outlays such as taxes, utilities, and insurance as of 2007. This pattern of high costs to support a housing position is interpreted as both a cause of and the result of a speculative price run-up based on naïve expectations of persistent house price increases and supported by the joint decisions of the homeowners and their lenders. If all homeowners in a given market allocate more to hold their housing position, they are at the same time part of the effective demand that sustains and boosts short-run home prices.

The year of taking the original mortgage, the rate of decrease in the Case-Shiller home price index, and household wealth level also are substantial predictors of mortgage payment distress in 2009 (Stafford, Hurst, and Chen, 2012). Yet, the financial crisis, while an important factor in motivating withdrawals from pension balances, is part of a wider pattern of pre-retirement pension transactions. We would like to understand this wider set of factors that lead a family to withdraw funds or 'borrow' from their pensions prior to retirement (Lu and Mitchell, 2010). Our prior research shows that much of the rise and subsequent mortgage difficulties were concentrated among younger and less educated homeowners. To what extent did families turn to pension funds to alleviate the cash flow crisis?

With the housing, equity and bond market losses did both housing and DC pensions lose favor? While there is evidence of Bayesian learning to create financial knowledge capital (Kédzi and Willis, 2011), many young families may hold a diffuse prior and respond strongly to the perceived and expected returns in the financial and housing markets based on current experience. Even older families may not have 
sufficient knowledge capital to discount recent movements and may respond in a naïve way. If there are adverse experiences in both the equity and housing markets, with Bayesian learning, there can be increased interest in holding other assets.

\section{The Research Plan}

We study the range of factors leading to life course pension withdrawals as well as pension contributions. Are pensions now becoming another form of financial net worth accessible as a buffer stock to a range of cash flow and expenditure outlays prior to retirement? We plan to investigate six questions.

(1.) What has been the emerging pattern of coverage and coverage transitions, 1999-2009? Does participation appear to depend on anticipated returns on fund investments?

(2.) What factors are leading to withdrawals from DC pensions, 1999-2009? Are families drawing money out in response to cash flow needs from unexpected expenses or declines in earnings throughout the range of pre-retirement ages? Are they responding to the provisions that eliminate the penalty for withdrawals for medical needs at age 59 when the withdrawals are exempt from penalty? Do expenditures on durables appear to induce pension withdrawals?

(3.) Does mortgage foreclosure, and inability (or unwillingness) to continue mortgage payments, depend, in a significant fraction of cases, on recessionary unemployment? If so, did cash flow needs arising from mortgage payment problems and unemployment during the Great Recession lead to more pension withdrawals, 2007-2009?

(4.) Which groups are saving more in the form of pension contributions? At the present stage of the financial crisis, personal savings rates are rising and households are reducing their debt obligations (Federal Reserve Board, 2012). One pattern we can see from an analysis of the preliminary 2011 early files on housing and wealth (which include questions on liquid assets and also funds into and out of pensions by 
family) is an increase in the percent of homeowners with no mortgage, and a buildup of liquid assets, 2009-2011, by families with liquid assets greater than $\$ 50,000$ as of 2009 (Stafford, Chen and Schoeni, 2012).

Possibly the shift to greater liquidity and to less debt reflects a decision of families to save by clearing out some debts - along with a newfound caution on the part of potential lenders. Are some of these families putting more aside in the form of pensions as another way to increase their liquidity or to save more for a more uncertain future retirement? ${ }^{4}$

(5.) Which married men are making contributions to their pension plans and how has this differed in relation to overall financial market returns?

(6) How are defined-contribution pension accounts faring (i.e., are they being cashed in to meet more immediate obligations)? Or conversely, does concern over the uncertain economy lead some families to put money aside - including increasing the funds put into their pensions? Are current responses to the crisis stripping away pension assets that will be missed by retirees in the future?

\section{Conceptual Framework}

The approach to the analysis here is the possible use of DC pensions as a midterm financial asset with more general uses than solely a lifetime pension. In this view, while pensions have as their primary purpose the accumulation of wealth during the working years to sustain consumption during retirement, in practice, once a balance has accumulated, these funds, just as for financial assets such as CD's or saving accounts, can serve a buffer stock role to cover both unanticipated declines in cash flow income and unanticipated expenses. Such behaviors could be accentuated by

\footnotetext{
${ }^{4}$ Data from the Federal Reserve Flow of Funds (Federal Reserve 2012) indicate a persistent decline in Individual Retirement Account (IRAs) from a high of \$275.7 (billion) in 2007 to \$198.6 in 2009 and \$20.1 in 2011. The aggregate private pension funds have several components, so the overall pension savings rate is more complex. At the individual level, there will still be wide variations in pension savings which we plan to assess.
} 
families learning, both individually and collectively, to tap into pensions for other more predictable and discretionary or durable items, such as purchasing a vehicle or other major expenditures. One framework which can be used is that of an intertemporal perspective within a lifetime setting - but one in which there are short run shocks to income and unanticipated expenditure needs.

A class of models which offers a framework for such behavior is a more generalized version of the Stone-Geary expenditure model. The attraction of this approach is that it sets out the role of shocks to both income and expenditure and develops a basic connection of current income and expenditure shocks as shaping the dynamic value of a unit of additional assets over the planning horizon for the purpose of deciding on current expenditure. The original model of Klein and Rubin (1948) evolved to the generalized 'linear expenditure system' of Stone and was later set out more fully (Brown and Helen, 1972). The key element is the expression for utility of a set of goods $\left(\mathrm{x}_{\mathrm{i}}\right)$ :

(1) $\mathrm{U}=\mathrm{U}\left[\left(\mathrm{x}_{1 \mathrm{t}}-\omega_{1 \mathrm{t}}\right),\left(\mathrm{x}_{2 \mathrm{t}}-\omega_{2 \mathrm{t}}\right),\left(\mathrm{x}_{3 \mathrm{t}}-\omega_{3 \mathrm{t}}\right), \ldots\right]$ where $\omega_{\mathrm{it}}$ are the 'needs' and $\mathrm{U}(\cdot)$ is of a functional form (e.g., logs) which has the needs as 'required' to be met. With more than two goods this allows for possible substitutes or complements and needs can be subject to shocks, as with unexpected medical expenditures. The asset accumulation equation is given as:

(2) $\mathrm{S}_{\mathrm{t}}=-\left(\mathrm{p}_{1 \mathrm{t}} \mathrm{x}_{1 \mathrm{t}}+\mathrm{p}_{2 \mathrm{t}} \mathrm{x}_{2 \mathrm{t}}+\mathrm{p}_{3 \mathrm{t}} \mathrm{x}_{3 \mathrm{t}} \ldots\right)+\mathrm{w}_{1 \mathrm{t}} \mathrm{L}_{1 \mathrm{t}}+\mathrm{w}_{2 \mathrm{t}} \mathrm{L}_{2 \mathrm{t}}+\ldots$ and

(3) $A_{t}=s_{0 t}+s_{1 t}+s_{2 t}+\ldots+s_{n t}+A_{t-1}+\delta_{t 1}+\delta_{2 t}+\delta_{n t}$

Where A is Net worth, s represents savings flow components and $\delta$ represents returns/losses by component, and $A_{i}$ represents the separate net worth and pension components. The presence of separate asset categories, including pensions, serves to place the pension decision in the wider context of portfolio choice. Labor income of the family members, $\mathrm{w}_{1 \mathrm{t}} \mathrm{L}_{1 \mathrm{t}}+\mathrm{w}_{2 \mathrm{t}} \mathrm{L}_{2 \mathrm{t}}$, can be simplified as the uncertain inflow, $\mathrm{s}_{0 \mathrm{t}}$. 
Most savings components are perfect substitutes going into net worth but may not be perfect substitutes when coming out into cash for spending. ${ }^{5}$ Of interest is special tax treatment of funds into a pension and coming out compared to non-pension saving. Here the possible penalties on or subsidies to pension withdrawals prior to retirement can be considered. Money to cover expenses reduces the rate of asset inflow and may come out of $\mathrm{a}_{0 \mathrm{t}}$, the pension balance component of net worth.

For pension funds in different asset classes, as suggested by recent research on financial market expectations (Hurd and Rohwedder, 2012; Dominitz and Manski, 2011; Hudomiet, Kédzi and Willis, 2011), a change in observed returns will shape expected returns in a naïve fashion for those who believe that recent market performance will persist into the future. Further, expectations for future returns in an asset category appear to be heterogeneous, so the expectations change and related responses will likely be household specific. Some may believe returns on stocks or bonds form a random walk and discount short-term movements - implying asset allocation based on long-term returns.

Of course, financial behavior should be shaped by both expectations and cooccurring life events. The nature and extent of the responses to changing returns when combined with life events is rather unknown. Lower expected financial returns on a major asset class, such as equities or bonds, could plausibly boost overall savings as well as an allocation away from the assets with reduced expected returns, both within and outside of the pension holdings. In the context of asset allocation models (Campbell and Viciera, 2001), the perception of future labor income risk can induce a reallocation to assets with a lower variance on returns and a lower expected return. ${ }^{6}$

\footnotetext{
${ }^{5}$ One cost of transactions is decision costs in light of assessing current and future needs. In this context, there are fixed costs so an exogenous event such as a job loss will lead to several choices, including pension decisions on withdrawal and rollover.

${ }^{6}$ The observed shift to greater liquid financial assets, 2009-2011, by those with greater initial liquid assets is consistent with either increased saving, a reallocation from other assets, or both.
} 
The financial incentives to participate are shaped by employer matching of inflows, $\left(1+k_{t}\right)$ per dollar, where $k_{t}$ is the matching rate. At this level alone, it can be seen that for an expenditure which is exempt from withdrawal penalty, combined with employer matching of a substantial percentage of the DC pension, there will be a 'revolving door' attraction of pension contributions. For a dollar going in at $\left(1+\mathrm{k}_{\mathrm{t}}\right)$ and going out at 1 , there is a savings discount on such pension-based expenditures over direct payment of $1 /\left(1+k_{t}\right)$. If expenditures on such categories are anticipated, the family should certainly want to put in subsidized (and tax exempt dollars) to pay for them rather than directly out of $\mathrm{s}_{0 \mathrm{t}}$ or other assets, up to the limit of such contributions by the employer or the tax code. Some employers have mandatory participation in the DC plan as a condition of employment or may urge participation as the default option. And despite this directive or 'nudge' the employee can subvert the employer's intentions via subsequent active pension withdrawals. The use of pensions for tax-free and possibly employer-subsidized dollars may compete with health savings accounts (HSAs). HSAs also allow tax exempt dollars to go in, but restrict the withdrawal to health expenditures and, under certain conditions, may also have an employer match. ${ }^{7}$

Excluding the matching subsidy notation, all the variants of the consumption model have demand expressions such as:

$$
X_{i}=\omega_{i t}+\beta_{i} p_{i}^{-1}\left[m-\left(p_{j 1 t} x_{j 1 t}+p_{j 2 t} x_{j 2 t} p_{k 3 t} x_{k 3 t} \cdots\right]\right.
$$

Where $\mathrm{m}$ is money income and savings inflows or outflows - and the savings are also shaped by positive and negative returns $(\delta$ 's). What stops spending short is the usual $A>0$ constraint, and $\lambda_{A}$, the companion dynamic value of a dollar in various net worth components as people look forward into the future and anticipate future cash flow needs and other financial events. So a dollar of spending on food out of

\footnotetext{
${ }^{7}$ http://www.irs.gov/publications/p969/ar02.html\#en_US_2011_publink1000204101
} 
home has the current dollar 'price', $\mathrm{p}$, but for each dollar spent there is a 'markup' in the sense that it is depleting or not adding to net worth. That is,

(5) $\partial \mathrm{U} / \partial \mathrm{x}_{\mathrm{i}}=\mathrm{p}_{\mathrm{i}} \lambda_{\mathrm{A}}$.

Where the $\lambda_{\mathrm{A}}$ serves to increase the full price of spending when financial balances are low or other expenditure needs are foreseen. Conversely, with a positive cash flow shock from the labor market or asset returns - this will reduce the shadow price of a dollar and induce added spending on various X's in line with the price elasticity and substitutability and complementarity of the $\mathrm{X}$ in question. If expected future financial market returns fall or and no current spending need shock arises, the value of $\lambda_{\mathrm{A}}$ will rise, leading to saving out of current income flows and asset reallocation away from assets seen to have reduced or risky returns, since adverse shocks will compromise future consumption. And there can be the obvious tension if the future is foreseen to have cash flow reductions but the present also has limited resources; one force suggesting to save, the other suggesting to spend on 'necessities' given a limited budget and high current marginal utility of spending more on current $\mathrm{X}_{\mathrm{i}}$ 's, as well as a substitution to less expensive forms for a given expenditure domain such as substituting home meals for meals out and lowering transportation costs in various ways.

The basic result of incentives to save or dissave is set out in Table 1. The marginal utility of an additional dollar of current spending if resources are limited to current cash flow, $\mathrm{MU}_{\mathrm{CCF}}$, is low and the future value for anticipated spending ${ }^{8}$ relative to all future cash flow, $\lambda_{\mathrm{A}}$, is high, there will be clear savings incentives (S). Conversely, if based on current cash flow, the value of added spending is high - from an unforeseen increase in needs $\left(\omega_{1 t}\right)$ or a reduced cash flow - there will be incentives to dissave (D) if future income looks promising. As can be seen there are cases where

\footnotetext{
${ }^{8}$ This includes future spending in retirement and also the value the family places on bequest
} 
the current versus future incentives for saving are at odds and the net incentives to save or spend out of assets is unclear.

\begin{tabular}{|c|c|c|}
\hline \multicolumn{3}{|c|}{$\begin{array}{l}\text { Table 1. Saving to Balance Current and Future Spending } \\
\text { Needs } \\
\text { (Value of a dollar over remaining horizon }\left(\lambda_{\mathrm{A}}\right)\end{array}$} \\
\hline & Lower & Higher \\
\hline $\begin{array}{c}\mathrm{MU}_{\mathrm{CCF}} \\
\text { Low }\end{array}$ & $?$ & $\mathrm{~S}$ \\
\hline $\begin{array}{l}\mathrm{MU}_{\mathrm{CCF}} \\
\text { High }\end{array}$ & $\mathrm{D}$ & $?$ \\
\hline
\end{tabular}

The effects of short-run cash flow and needs shocks on variations in pension or other balances will be less variable and important if $A>0$ after midlife and, but there can be big shocks - tuition, health expenditures, or an earnings cash flow shock from a long spell of unemployment, which will bring to the fore the immediate utility value of various expenditures. And those who are in midlife - while having other alternatives to finance such short-term expenditures, will also have a larger pension balance to work with and may have better awareness of the advantages of pension based transactions. ${ }^{9}$

For the case of a consumption need, $\omega_{\text {it }}$, increasing, the expected result is a shift from other expenditures and a withdrawal from assets, including a pension fund withdrawal. If a series of expenditures have been covered by pension withdrawals, the value of a dollar allocated to future expenditures will have risen, inducing rebuilding

\footnotetext{
${ }^{9}$ Falling stock market prices, for those with naïve persistence expectations (Dominitz and Manski, 2011), may induce a shift to other assets and an apparent increase in financial saving in alternative financial assets.
} 
of the depleted savings. ${ }^{10}$ This suggests that those not adversely affected by short run events may, in anticipation of future uncertainties during a recession, increase their current savings, possibly in the form of pension participation or increased contributions. Suppose, however, that the family experiences initial and then additional negative income shocks. At some point, the best option can be bankruptcy or foreclosure. In such default cases the family will face a new regime going forward. The new dynamic program can be represented as the baseline less a recurring financial or utility penalty from the default. So, while managing finances to avert a default is the more likely path, some families will find it more attractive to default, reducing short run costs but bringing on a longer term financial or utility penalty.

Aside from default or foreclosure, with a negative income shock or wealth loss,

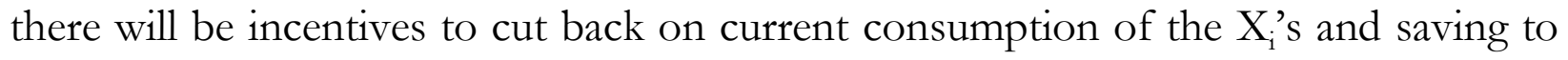
restore net worth, and if such shocks are foreseen in the future and responded to, this will induce a greater value of $\lambda_{A}$, leading to more current savings. It is as if current consumption on a given $\mathrm{X}_{\mathrm{i}}$ has a markup based on the anticipated future value of a dollar in the remaining plan and the value of lowering the risk of a default penalty. Also, a negative shock to a given net worth component can induce an effort to replenish various net worth components and save for eventual retirement.

How strongly families respond to future needs will depend on a subjective discount factor which can be added to the discounted value of (1) over the remaining planning period. A high subjective discount rate will lead to more response to shortrun factors and would lead to less financial reserves in general. The subjective discount will play a major role in the extent to which the portfolio, including pensions, is shaped by longer term events. Data from the 2004 Survey of Consumer

${ }^{10}$ PSID data for 2009-2011 indicate a bifurcation in the changes in the family holdings of liquid assets. As of $2009,18.5 \%$ of families had no liquid assets, and by 2011 this had grown to $23.4 \%$ of families. At the same time, the overall percentage of families in the highest category of $\$ 50,000$ or more in liquid assets increased from $11.8 \%$ to $14.6 \%$ (Stafford, Chen and Schoeni, 2012) 
Finances indicate a very strong relationship between pension participation and a measure of subjective discounting (Chiteji, Gouskova and Stafford, 2010). And of those with a pension, having a high subjective discount would be a likely predictor of responding to shorter run financial conditions, including participation itself. In addition, pension contributions out of current cash flow can be shaped by expected returns on the investments in a DC plan. With optimistic expected returns on pension fund holdings a result may be a wealth effect on prior allocations reducing current savings, as there seems to be from non-pension wealth (Juster, et. al, 2006). For those in a DB plan the expected returns are less salient, conditional on fund solvency.

\section{Pension Fund Balance and Activity Patterns, 1999-2009}

From 1991-2000 the flow of funds data indicate a shift away from equity in defined benefit plans and into defined contribution plans (Teplin, 2001, p. 437) ${ }^{11}$. The long-run cohort-based shift away from DB pensions is well-documented, and recent movement (1992-2007) in coverage by type is parallel for men and women (Heiland and $\mathrm{Li}, 2012)$. Here we begin with the basic pension patterns for married men over the period 1999-2009. The period includes end of a boom, a recession, a recovery and yet another recession. The overview is based on constructing five balanced two-year panels of married men 1999-01, 2001-03, 2003-05, 2005-07 and 2007-09. The age ranges for each balanced panel are: 25 to 62 and (approximately) age 27-64. The rationale for studying married men is to focus on those men who would be of normal full-time employment age and thereby more likely to hold a pension or IRA. In Table 2, the basic descriptive statistics for these two-year panels with end year sample weights are presented.

\footnotetext{
${ }^{11}$ As of 1991 household sector holdings of equity in private DB plans accounted for 10.6 percent of total equity holdings, and this fell to $7.5 \%$ by the year 2000. In contrast, as of 1999 equity in private DC plans accounted for 8.7 percent of equity holdings and by 2000 this had risen to 10.5 percent. Moreover, as of early 2000 the stock market was at a peak prior to $9 / 11$.
} 
Two main patterns are consistent with various cross-sectional analyses ${ }^{12}$. First, there is a shift to a somewhat lower percent of married men with solely a DB plan. This is apparent and persistent among all - whether in the labor market or not. Overall, there are about 20 percent of those in the labor market with a DC plan only. ${ }^{13}$ But when the $\%$ Both ${ }^{14}$ is factored in, the percent with solely a DC plan or a DC plan in conjunction with a DB plan, the percent with a DB is about 30 percent ${ }^{15}{ }^{16}$. The percent in the labor force with no pension coverage rises from 45 percent to about 50 percent after 2001. While the differences are not dramatic, the reduction in the percent of DC plans after 2001 may plausibly reflect the combined effects of the recession in late 2001 and a response to the related stock and bond market declines in 2001-2002. In any event the two most identifiable patterns are the shift out of DB plans and a shift to no coverage for those in the labor force after 2001, primarily between 1999-2001 and 2001-2003.

\footnotetext{
${ }^{12}$ Teresa Ghilarducci et al., "Power and Pensions: Historic Declines in Pension Coverage," PowerPoint presentation, Michigan Retirement Research Center Workshop, University of Michigan, Ann Arbor, Michigan April 13, 2012.

${ }^{13}$ Dushi and lams indicate a moderate increase in DC coverage based on SIPP and matched SSA W-2 records (2010, see Table 1$)$.

${ }^{14}$ The question on whether the pension is a DC a DB or both is problematic in that the answer of 'both' has some with two distinct pension types or components separately, but may also be somewhat inflated if those who have a DB are thinking of the fact that there is a reserve fund associated with the actuarial structure of the plan, and they are making contributions to that fund.

${ }^{15}$ Data from the U.S. Department of Labor, Bureau of Labor Statistics from the National Compensation Survey indicate that 10 percent of establishments offer defined-benefit plans compared to 43 percent that offer a DC plan only, but some employers do offer both. Both defined benefit and defined contribution plans are more common in larger establishments. http://www.bls.gov/ncs/ebs/benefits/2011/ownership/private/table01a.pdf

${ }^{16}$ Data for 2006 from SIPP, which has a more inclusive definition of contributing, indicate that $39 \%$ of fulltime workers age 21-64 contribute. Private sector employees who make a contribution to a tax-deferred investment account are defined as DC participants (Dushi and lams, 2010, Table 1). PSID data include selfemployed persons who were active in the labor market who may not have a pension or $\mathrm{W}-2$.
} 
Table 2. Pension Status \% and DC and DB Trends 1999-2009

(Balanced 2-Year panels, Married Men, age 25-63, $(\mathrm{t}, \mathrm{t}-2)$ )

\begin{tabular}{|c|c|c|c|c|c|}
\hline ENDING YEAR & $\% \mathrm{DC}$ & $\% \mathrm{DB}$ & $\%$ Both & $\%$ Neither & Not in L F \\
\hline \multicolumn{6}{|l|}{ Percent of } \\
\hline 2001 All & 18.5 & 19.9 & 11.2 & 40.1 & 10.3 \\
\hline 2001 Employed & 20.7 & 22.2 & 12.5 & 44.7 & \\
\hline 2003 All & 15.5 & 18.4 & 9.8 & 43.4 & 12.8 \\
\hline 2003 Employed & 17.7 & 21.1 & 11.3 & 49.8 & \\
\hline 2005 All & 15.8 & 18.9 & 9.0 & 45.2 & 11.1 \\
\hline 2005 Employed & 17.7 & 21.3 & 10.1 & 50.8 & \\
\hline 2007 All & 18.1 & 18.7 & 8.9 & 43.0 & 11.3 \\
\hline 2007 Employed & 20.4 & 21.1 & 10.1 & 48.4 & \\
\hline 2009 All & 15.1 & 17.0 & 10.5 & 42.3 & 15.2 \\
\hline 2009 employed & 17.7 & 20.0 & 12.3 & 49.9 & \\
\hline
\end{tabular}

The transitions into holding a sole DC pension are presented in Table 3, and the percent covered by a DC plan is in the $16-20$ percent range. The percent of employed with solely a DC is near 20 percent as of 2001 and falls to an even lower percent before recovering in $2007^{17}$. While the transitions partly reflect response error, assuming that to be stable across the data panels, the flow from DB and BOTH into DC seems to be greatest as of 1999-2001. Since most of the 2001 data were collected prior to $9 / 11$, the stock market and other financial markets would have likely been

\footnotetext{
${ }^{17}$ The percent with a DC plan differs from Table 1, since for the balanced panel transitions pension status needs to be reported in both the beginning and ending of the two-year period.
} 
seen as a good place to invest, 1999-2001, ${ }^{18}$ and this could explain the more substantial inflow to DC plans from the DB and Both categories, 1999-2001. This transition pattern is consistent with the result in Table 4, showing that, for our repeated balanced panels, 1999 - pre 9/11, 2001 was the high water mark for DC pensions.

As DC pension growth stalled with the falling stock and bond markets, exit from DCs to no pension coverage can describe the shift away from pensions as of 2001-2003 ${ }^{19}$ and continuing into 2003-2005. Conversely, with the recovery in equities and bonds, 2003-2007, we see an increased rate of participation in DC pensions ${ }^{20}$. This pattern suggests there is some chasing of returns or 'momentum investing', a naïve expectations of persistence of recent returns, or responses to changing nonpension liquidity during expansions and contractions. ${ }^{21}$ This response is again reflected in the falling percentages of DC pensions, 2007-2009 - whether based on the full sample or the employed subsample. In contrast, there is a modest but steady downward trend in DB plan coverage, and this seems not to be changing as the financial markets went through the two booms and recessions.

\footnotetext{
${ }^{18}$ The Standard \& Poor's 500 began moving downward in 2000, but the two-year moving average started a steep decline later in 2001 and accelerated after 9/11.

${ }^{19}$ Data from the Survey of Economic Expectations and the Michigan Survey of Consumers show a clear shift downward in the percent of respondents expecting a positive nominal return on equities, from September 2000 - March 2001 going forward to the spring of 2003, with expectations lagging the return on the S\&P a year prior (Dominitz and Manski, p. 356-357).

${ }^{20}$ The Pension Protection Act of 2006 was designed to expedite enrollment and management of $401(\mathrm{k}) \mathrm{s}$ through the use of automatic enrollment, mostly impacting new employees, and the option to apply simple asset allocation rules and contribution rates increasing through time. See Alicia H. Munnell, "401(k) Plans in 2010: An Update from the SCF," Center for Retirement Research, July 2012, Number 12-13. The impact of the PPA is less apparent going forward from 2006 into the 2008-2009 recession and SCF data show erosion in the form of 401(k) loans rising to 16 percent from 13 percent I 2007, and some increase in non-participation, 2007-2010.

${ }^{21}$ In addition, there was some discontinuance of employer matching in the post-9/11 recession, but more in the 2008 financial crisis (Munnell and Quinby, 2010)
} 
Table 3. Transitions to Defined Contribution Plans From Prior Pension States as of Ending Year

\begin{tabular}{|c|c|c|c|c|c|c|}
\hline & & & & & & \\
\hline & & & $\% \mathrm{D}$ & (t) from $\mathrm{O}$ & $\sin (t-2)$ & \\
\hline & & Only & Only & & & \\
\hline Percent of & $\begin{array}{c}\text { With DC } \\
\text { only }\end{array}$ & $\mathrm{DC} \%$ & $\mathrm{DB} \%$ & Both $\%$ & $\%$ Neither & $\begin{array}{c}\% \\
\text { NILF }\end{array}$ \\
\hline 2001 All & 17.9 & 7.1 & 3.6 & 2.4 & 4.7 & 0.1 \\
\hline 2001 Employed & 20.1 & 8.0 & 4.0 & 2.7 & 5.3 & 0.1 \\
\hline 2003 All & 14.9 & 7.3 & 1.7 & 2.0 & 3.7 & 0.3 \\
\hline 2003 Employed & 16.4 & 8.1 & 1.8 & 2.2 & 4.0 & 0.3 \\
\hline 2005 All & 15.5 & 6.1 & 2.8 & 1.8 & 4.1 & 0.6 \\
\hline 2005 Employed & 17.5 & 6.9 & 3.2 & 2.0 & 4.7 & 0.7 \\
\hline 2007 All & 17.3 & 7.1 & 1.8 & 1.8 & 5.9 & 0.8 \\
\hline 2007 Employed & 19.2 & 7.9 & 2.0 & 2.0 & 6.5 & 0.9 \\
\hline 2009 All & 14.6 & 7.3 & 1.8 & 1.3 & 3.9 & 0.2 \\
\hline 2009 Employed & 16.2 & 8.1 & 2.0 & 1.4 & 4.4 & 0.2 \\
\hline
\end{tabular}

For 2003-2007 there were substantial inflows into sole DC status and into no coverage as part of the transition away from DB plans. The shift away from DB plans is set out in Table 4. The percent of employed married men with a DB plan drops from 21.6 percent in the 1999-2001 panel to 19.0 percent in the 2007-2009 panel. Through the waves the percent of recurring DB coverage drops from $12.2 \%$ in 1999 2001 to $10.9 \%$ in $2007-2009$. This pattern of panel changes is consistent with the DB decline set out in Table 1. 
Table 4. Transitions to Defined Benefit Plans from Prior Pension States as of Ending Year

\begin{tabular}{|c|c|c|c|c|c|c|}
\hline & & & $\% \mathrm{D}$ & $(\mathrm{t})$ fron & rigin $(t-2)$ & \\
\hline & & Only & Only & & & \\
\hline Percent of & $\begin{array}{c}\text { With } \\
D B \text { only }\end{array}$ & $\mathrm{DC} \%$ & $\mathrm{DB} \%$ & Both $\%$ & $\%$ Neither & $\%$ NILF \\
\hline 2001 All & 19.2 & 2.3 & 10.9 & 3.7 & 1.9 & 0.5 \\
\hline 2001 Employed & 21.6 & 2.6 & 12.2 & 4.1 & 2.1 & 0.5 \\
\hline 2003 All & 18.1 & 2.6 & 10.5 & 3.5 & 1.4 & 0.1 \\
\hline 2003 Employed & 20.0 & 2.9 & 11.5 & 3.9 & 1.5 & 0.1 \\
\hline 2005 All & 18.6 & 2.5 & 10.5 & 3.6 & 1.7 & 0.4 \\
\hline 2005 Employed & 21.0 & 2.8 & 11.8 & 4.0 & 2.0 & 0.4 \\
\hline 2007 All & 18.3 & 2.4 & 10.2 & 2.9 & 2.6 & 0.2 \\
\hline 2007 Employed & 20.3 & 2.7 & 11.3 & 3.2 & 2.9 & 0.2 \\
\hline 2009 All & 17.1 & 2.0 & 9.8 & 3.0 & 2.1 & 0.2 \\
\hline 2009 Employed & 19.0 & 2.3 & 10.9 & 3.3 & 2.3 & 0.2 \\
\hline
\end{tabular}

To complete the pension transition picture, Table 5 presents the share of married men with no pension coverage. Of employed men in the 1999-2001 panel, 46.2 percent had no pension coverage. The percent not covered rises to 52.1 percent in 2005, but drops downward with the better economy in 2005-2007. Going forward to 2009, the percent not covered remains below the peak in 2005. An explanation could be a type of composition bias (Solon, Barsky and Parker, 1994) in which the workers with no pension are more likely to exit the labor force as of 2009. The transition into 'no plan' from DC pension status increases during 2001-2003, and then declines until 2007. Then, in 2009, 
with the recession underway, ${ }^{22}$ an increase in the shift from DC to 'no plan' rises once again to 4.7 percent for the employed sample. Whether these shifts were induced by changing expected returns (elements in $\lambda_{A}$ ) or from increased utility value of a added dollar of consumption from current cash flow $\left(\mathrm{MU}_{\mathrm{CCF}}\right)$ is uncertain.

While the issue of consistent reporting of the type of pension coverage is a concern, the question of errors in reporting no coverage versus some type of coverage is reflected in the percent reporting no plan or not being in the labor force in the prior wave. For the panel from 1999-2001, of the 46.2 percent of the employed with 'no plan', 37.0 percent (or 80\%) were in the 'no plan' or out 'of the labor force' as of 1999.

Table 5. Transitions to No Pension Plan from Prior Pension States as of Ending Year

\begin{tabular}{|c|c|c|c|c|c|c|}
\hline \multirow{4}{*}{$\begin{array}{l}\text { Percent of } \\
2001 \text { All }\end{array}$} & \multirow{4}{*}{$\begin{array}{r}\text { No Plan } \\
41.2 \\
\end{array}$} & \multicolumn{4}{|c|}{$\%$ NO PLAN $(\mathrm{t})$ from Origin $(\mathrm{t}-2)$} & \multirow{3}{*}{$\begin{array}{c}\% \\
\text { NILF }\end{array}$} \\
\hline & & \multirow{2}{*}{$\begin{array}{l}\text { only } \\
\text { DC\% }\end{array}$} & only & \multirow[b]{2}{*}{ Both $\%$} & \multirow[b]{2}{*}{$\%$ Neither } & \\
\hline & & & $\mathrm{DB} \%$ & & & \\
\hline & & 4.6 & 2.3 & 1.3 & 31.1 & 1.9 \\
\hline 2001 Employed & 46.2 & 5.1 & 2.5 & 1.4 & 34.9 & 2.1 \\
\hline 2003 All & 44.3 & 5.1 & 2.9 & 1.1 & 32.7 & 2.6 \\
\hline 2003 Employed & 48.7 & 5.6 & 3.2 & 1.2 & 36.0 & 2.8 \\
\hline 2005 All & 46.2 & 4.0 & 2.3 & 1.1 & 34.9 & 3.8 \\
\hline 2005 Employed & 52.1 & 4.5 & 2.6 & 1.3 & 39.4 & 4.3 \\
\hline 2007 All & 43.9 & 3.5 & 2.3 & 1.3 & 34.4 & 2.4 \\
\hline 2007 Employed & 48.8 & 3.9 & 2.5 & 1.5 & 38.4 & 2.6 \\
\hline 2009 All & 42.4 & 4.3 & 2.3 & 1.1 & 32.5 & 2.1 \\
\hline 2009 Employed & 47.1 & 4.7 & 2.6 & 1.3 & 36.1 & 2.4 \\
\hline
\end{tabular}

${ }^{22}$ The main flow of interviewing was spring to early fall in 2009. 
To summarize, while there is an increase in the share without a pension and a shift away from DB plans, there do also seem to be cyclical and financial market patterns operating; notably a shift away from DC plans from 2001-2003 when the stock and bond markets had become viewed as much less attractive as an investment target. The decade exhibited a less clear pattern in terms of DC coverage as some of the ground gained at one point seems to dissipate going forward. Also of note is that those not in the labor force as of $\mathrm{t}-2$ are far more likely to be without a pension than they are to achieve pension coverage by the end of each subpanel.

Here we have set out a background for the analysis of the financial management of DC pensions. The landscape of the pension data is characterized by numerous transitions. No doubt some of these are the artificial result of the difficulty in reporting coverage. However, the change in the transitions through time appears to be informative and to portray the evolving state of private pension coverage. These changing patterns provide context for the question of pension management as part of the family's overall finances. The somewhat mercurial nature of coverage may create an atmosphere in which the dollar amounts are not seen so much as part of a steady and rather passive long-run accumulation. Further, when transitions do occur for reasons such as job change, the reconsideration of the pension creates a decision window in which to re-allocate the balance for identified purposes. These purposes may be to cover unplanned expenditures or to simply find a convenient time to tap into the current pension balance for other spending.

\section{Pension Management}

\section{A. Life Course Cashing Out of Pensions}

Previous work has demonstrated the strong effect of having allocated a larger than normal share of income to support mortgage and other housing payments, often the result of refinancing in the $2004-2007$ period, as the strongest predictor of 
mortgage distress. In the context of the model in Section II, we can regard this as a major shock to wealth or collateral components. No longer could own home serve as collateral for borrowing and pension reserves, inducing the use of remaining assets for current expenditures. The cash flow to housing variable along with 2007 overall, nonpension net worth were both shown to be substantial predictors of mortgage distress. The extent of labor market difficulties for families in 2008, as well as the labor market status of the husband and wife as of the date of interview in 2009, were also found to be predictors of mortgage distress. The resulting adverse labor market outcomes induced by the contracting economy, 2008-2009, which occurred also in states with no housing boom and bust cycle, speaks to the interconnected elements in the economy and is of importance for understanding major local shocks as they work their way through the overall U.S. economy.

We have been able to look closer at the factors inducing the cashing in of a pension during the wider period, 1999-2009. While we know the responses in borrowing from the plan provisions (Lu and Mitchell, 2010), the range of life-cycle and other family factors that lead to cashing in are less well known. We know already that housing mortgage payment problems matter, and we have begun an assessment of events such as health shocks or cash flow problems. Moreover, these factors appear to be operating even in periods of overall economic expansion. Based on a pooled file of married couples 2007-2009, with at least one partner holding a DC pension, we have several preliminary results.

To start we have explored the responses to the question of having cashed in any amounts from a pension, private annuities or an $\operatorname{IRA}^{23}$. The age pattern is shown in Table 6. The data reflect both life-course and cohort effects seen in the analysis of SIPP data (Heiland and Li, Figure 3) as well as cumulative opportunities to withdraw

\footnotetext{
${ }^{23}$ The question was: 'Since January of (the full calendar year two years back) did you or anyone in your family cash in any part of a pension, private annuity or IRA?" The question for putting money in is slightly different: "Since January of 2007 did you or your family put aside any money in annuities or IRA's?"
} 
from a pension. The sample is restricted to those with a defined contribution pension (2,607 observations). It is clear that most of those with a DC pension are under age 62, a pattern consistent with the shift away from traditional DB plans. Of interest is the rather substantial use of pension withdrawals by those age 25-44 - about $6 \%$ reporting some cashing in of their pension. Another feature is the percent withdrawing when the head is age 59-61. At age $591 / 2$ the penalties to withdrawal are removed and the percent making a withdrawal jumps to 15.3 percent, quite close to the rate for the small sample of families age 65-66. Of those withdrawing at age 59-61 are they recidivists or - on the other hand - have they held off cashing in until that age, thereby avoiding a penalty? Or have others cashed in for categories exempt from a withdrawal penalty?

Table 6. Cashing In a Pension, Annuity of IRA over the Life Course, 2007-2009

\begin{tabular}{|c|c|c|}
\hline $\begin{array}{c}\text { Life Stage } \\
\text { (Age of Head) }\end{array}$ & Percent ${ }^{\mathrm{a}}$ Cashing In & Sample Size \\
\hline $25-34$ & 5.6 & 587 \\
\hline $35-44$ & 4.5 & 736 \\
\hline $45-58$ & 6.0 & 1,047 \\
\hline $59-61$ & 15.3 & 111 \\
\hline $62-64$ & 10.5 & 67 \\
\hline $65-66$ & 17.1 & 41 \\
\hline 67 or older & 5.6 & 18 \\
\hline & Weighted Average: 6.2 & Total: 2,607 \\
\hline
\end{tabular}

${ }^{a}$ PSID Sample weights 
While there is more cashing in at ages 59-61, almost as high as for ages 62-66, in a basic model with age and other covariates, there remains a noticeable shift to a higher rate of cashing in for ages 59-61, in line with reduced withdrawal penalties at age 59. So, as assets are run down the opportunity to transfer from a DC pension has much better terms starting at age 59 1/2.

Table 7 presents the pension contribution patterns during 1999-2009, of by one or more members of the family. As can be seen, the share of families with IRAs or annuities rises modestly between 1999 and 2001 and then declines somewhat going forward to 2009. Families who took money out in 1999 amounted to $7.4 \%(18.0 \%$ relative to those reporting an IRA or annuity). The boom prior to 2001 led to both a higher percent with an annuity or IRA and a smaller percent taking money out $(4.3 \%$ relative to 43.8 or $9.8 \%$ ). By 2009 a higher percent took money out relative to the share with an IRA or annuity (5.5 of $38.9 \%$ or $14.1 \%$ ).

Table 7. Holding IRA's or Annuities and Taking Money Out, 1999-2009 (Percent)

\begin{tabular}{|c|c|c|}
\hline Year & Family Has & Money Taken Out \\
\hline 1999 & 41.1 & 7.4 \\
\hline 2001 & 43.8 & 4.3 \\
\hline 2003 & 43.4 & 4.5 \\
\hline 2005 & 43.1 & 5.1 \\
\hline 2007 & 42.7 & 5.3 \\
\hline 2009 & 38.9 & 5.5 \\
\hline
\end{tabular}




\section{B. Cashing Out Factors}

We see that out-of-pocket health expenditures are strong predictors of pension cash-ins. Health expenditures out-of-pocket are a cash flow burden, often unexpected, and are also a category of withdrawal exempted from penalty. What are some of the basic predictors of taking money out of or putting money into a defined contribution plan? To begin, we present a baseline logistic model of cashing in, extending the exploration in Table 7. The predictors in Table 8 are the life-stage age groups, whether age 59-61, family income for calendar year 2008; wealth categories as of 2009 - starting with the excluded group of wealth less than $\$ 10,000$, out-of-pocket medical expenses. ${ }^{24}$ Also included is whether the family experienced some form of mortgage distress as of $2009 .{ }^{25}$ Here we can think of mortgage distress as a cash flow crisis and out-of-pocket medical expenses as expenditure shock - as set out in the conceptual model. These boost the incentive to allocate resources to the present - unless the future is perceived as having even less promise.

Not all families with pension resources anticipated the adverse future economic conditions as of 2007-2009. If so, they could have less incentive to weight the future value of resources and may have looked to boost current expenditures. Here we explored one component of durable goods spending, namely, additions and repairs to the home in excess of $\$ 10,000$. This predicts pension withdrawals and also predicts reduced pension contributions. So, it may be that such home improvement is related to a wider picture of optimism over both current and future economic circumstances.

\footnotetext{
${ }^{24}$ The out-of pocket medical expenses are the sum of outlays in 2007 and 2008 for hospital and nursing home; doctor, outpatient and dental bills; and prescriptions, in-home medical care, special facilities and other services.

${ }^{25}$ The index is the sum of four components: being behind on current mortgage payments, expecting to be behind on mortgage payments, having worked with a lender to modify or renegotiate the main mortgage, and mortgage foreclosure. See Stafford, Hurst and Chen, 2012.
} 
Having inherited more than $\$ 10,000$ has a positive relation to the family adding to annuities or IRA's. On the other hand, most of the factors that are correlated with taking money out have a negative correlation to putting money in. Notably, compared to the excluded age group of $<35$, younger families (age 35-58) were less likely to make contributions and those age 35-44 were more likely to make withdrawals. The behavior of the 35-44 age group suggests that pensions are subject to active management - sometimes with money going in and at other times money being withdrawn.

Those with more wealth and current income were more likely to make contributions. Those families experiencing mortgage distress were much less likely to make contributions and were far more likely to make withdrawals. The housing market difficulties appear to be a reason for both actively removing funds while at the same time passively failing to add to pension funds. Looking at income and the balance sheet, being in the range of low current income or having limited non-pension net worth is a strong predictor of 'borrowing from one's self'. 
Table 8. Family Level Cashing In of Pensions and Annuities and Putting Money into a Private Annuity or IRA, 2001-2009 (weighted logit)

\begin{tabular}{|c|c|c|}
\hline Predictor & Cashing Out & Putting Money In \\
\hline $\begin{array}{l}\text { Age } 35-44 \\
(<35 \text { excluded })\end{array}$ & $\begin{array}{l}.205^{* * *} \\
(.061)\end{array}$ & $\begin{array}{l}-.439 * * * \\
(.038)\end{array}$ \\
\hline Age 45-58 & $\begin{array}{l}.439 * * * \\
(.064)\end{array}$ & $\begin{array}{l}-.528^{* * *} \\
(.036)\end{array}$ \\
\hline Age 59-61 & $\begin{array}{l}.960^{* * *} \\
(.070)\end{array}$ & $\begin{array}{l}-.309 * * * \\
(.047)\end{array}$ \\
\hline Age 61-63 & $\begin{array}{l}1.152^{* * *} \\
(.074)\end{array}$ & $\begin{array}{l}-.916^{* * *} \\
(.058)\end{array}$ \\
\hline Age 64-65 & $\begin{array}{l}1.389 * * * \\
(.078)\end{array}$ & $\begin{array}{l}-.544 * * * \\
(.058) \\
\end{array}$ \\
\hline $\begin{array}{l}\text { \$ Out-of-pocket medical } \\
\text { and dental }\end{array}$ & $\begin{array}{l}.040^{* * *} \\
(.002)\end{array}$ & $\begin{array}{l}.001 \\
(.002)\end{array}$ \\
\hline $\begin{array}{l}\text { If additions } \\
\text { and repairs }>\$ 10 \mathrm{~K}\end{array}$ & $\begin{array}{l}.657^{* * *} \\
(.046)\end{array}$ & $\begin{array}{l}.248^{* * *} \\
(.028)\end{array}$ \\
\hline If Inherited $\$ 10 \mathrm{~K}>$ & $\begin{array}{l}-.018 \\
(.018)\end{array}$ & $\begin{array}{l}.223^{* * *} \\
(.040)\end{array}$ \\
\hline $\begin{array}{l}\text { Wealth } \$ 10,000-\$ 49,999 \\
\text { (<\$10K excluded) }\end{array}$ & $\begin{array}{l}-.290 * * * \\
(.067)\end{array}$ & $\begin{array}{l}.368^{* * *} \\
(.062)\end{array}$ \\
\hline $\begin{array}{l}\text { Wealth } \$ 50,000- \\
\$ 124,999\end{array}$ & $\begin{array}{l}-.3145^{* * *} \\
(.063)\end{array}$ & $\begin{array}{l}1.130^{* * *} \\
(.053)\end{array}$ \\
\hline Wealth $\$ 125,000-249,999$ & $\begin{array}{l}-.1672^{* * *} \\
(.063)\end{array}$ & $\begin{array}{l}1.669^{* * *} \\
(.052)\end{array}$ \\
\hline Wealth $>\$ 249,999$ & $\begin{array}{l}-.007 \\
(.058)\end{array}$ & $\begin{array}{l}2.478^{* * *} \\
(.051)\end{array}$ \\
\hline $\begin{array}{l}\text { Total family income } 2008 \\
(\$ 1,000)\end{array}$ & $\begin{array}{l}-.0016 * * * \\
(.0002)\end{array}$ & $\begin{array}{l}.0010^{* * *} \\
(.001)\end{array}$ \\
\hline Mortgage Distress Index & $\begin{array}{l}.4374 * * * \\
(.027) \\
\end{array}$ & $\begin{array}{l}-.295^{* * *} \\
(.031) \\
\end{array}$ \\
\hline Intercept & $\begin{array}{l}-3.072^{* * *} \\
(.060)\end{array}$ & $\begin{array}{l}-2.670 * * * \\
(.049)\end{array}$ \\
\hline
\end{tabular}

Of those cashing in a pension, what amounts are reported to have been drawn out by year? Table 9 shows the percentile points of amounts withdrawn conditional 
on having made a withdrawal. At the $20^{\text {th }}$ and $40^{\text {th }}$ percentiles, the withdrawals have modest variations across the years and do not have a distinct shift for the years preceded by financial market declines (2003 and 2009). For the more substantial withdrawals - the $60^{\text {th }}$ and $80^{\text {th }}$ percentiles - withdrawals are distinctly larger when referring to immediate prior periods of financial market decline. Specifically, at the $80^{\text {th }}$ percentile the withdrawal rises from $\$ 18,174$ in the 2001 data to $\$ 31,901$ in 2003 . Data. Between 2007 and 2009, the $80^{\text {th }}$ percentile value of withdrawals rises from $\$ 23,009$ to $\$ 27,526$. If a pension wealth effect were operating strongly, one may expect larger withdrawals in conjunction with strong financial market appreciation, 1999-2001 and 2005-2007. To the contrary, these patterns suggest substantial liquidation at times when the market values have recently fallen. The response may be both immediate cash flow needs for current consumption as in Table 1, or it could reflect naïve expectations of additional years with poor returns in financial markets and a reallocation to other portfolio components.

Table 9. Percentile Distribution of Amounts Withdrawn, 1999-2009

\begin{tabular}{|l|c|c|c|c|c|c|}
\hline Percentile & $\mathbf{1 9 9 9}$ & $\mathbf{2 0 0 1}$ & $\mathbf{2 0 0 3}$ & $\mathbf{2 0 0 5}$ & $\mathbf{2 0 0 7}$ & $\mathbf{2 0 0 9}$ \\
\hline 20 th & \begin{tabular}{|l}
$\$ 2,387$ \\
$(265)$
\end{tabular} & $\begin{array}{c}\$ 1,989 \\
(341)\end{array}$ & $\begin{array}{c}\$ 1,977 \\
(290)\end{array}$ & $\begin{array}{c}\$ 1,783 \\
(398)\end{array}$ & $\begin{array}{c}\$ 1,965 \\
(265)\end{array}$ & $\begin{array}{c}\$ 1,942 \\
(330)\end{array}$ \\
\hline $40^{\text {th }}$ & $\$ 4,200$ & $\$ 4,438$ & $\$ 5,582$ & $\$ 3,995$ & $\$ 4,332$ & $\$ 4,969$ \\
& $(498)$ & $(695)$ & $(1,630)$ & $(622)$ & $(966)$ & $(712)$ \\
\hline $60^{\text {th }}$ & $\$ 9,214$ & $\$ 9,543$ & $\$ 12,586$ & $\$ 11,871$ & $\$ 10,615$ & $\$ 13,830$ \\
& $(1,373)$ & $(1,796)$ & $(2,433)$ & $(2,138)$ & $(1,798)$ & $(2,822)$ \\
\hline $80^{\text {th }}$ & $\$ 21,718$ & $\$ 18,174$ & $\$ 31,901$ & $\$ 31,215$ & $\$ 23,009$ & $\$ 27,526$ \\
& $(3,432)$ & $(2654)$ & $(6,860)$ & $(7,093)$ & $(3,679)$ & $(5,074)$ \\
\hline
\end{tabular}




\section{Pension Contributions by the Husband}

Each person who is employed is asked of their current contributions to a pension $^{26}$, along with some of the conditions for participation. Using these measures, we can extend the added and forgone contributions perspective at the family level to the individual pension contributions of the husband. The descriptive pattern by survey year is presented in Table 10. Here we assess whether the contributions of those who are covered under a pension plan (of the husbands who are <age 63) made contributions as of 2007-2009). As can be seen, there is once again a relation with financial markets and the macro-economy, with contributions declining after the booms of 1999-2001 and 2005-2007. In Table 11, we present a logistic regression of the pension contribution decision of the husbands. The model includes the family's net worth position, income from the prior calendar year, an illustrative expenditure shock variable, out-of pocket medical expenses, survey year (1999 excluded), and if contribution to a pension fund is required by the employer.

\footnotetext{
${ }^{26}$ This is based on the coverage question used for Table 2 : (if covered by a pension) "Are you making contributions to your pension or retirement account such as having money deducted from your pay?"
} 
Table 10. Married Men's Contributions to Own Pension, 1999-2009 (percent)

\begin{tabular}{|c|c|c|c|c|}
\hline Year & Money In & No Money In & No Pension & N.A./D.K. \\
\hline 1999 & 32.5 & 18.3 & 47.2 & 2.1 \\
\hline 2001 & 35.4 & 15.8 & 48.1 & 0.8 \\
\hline 2003 & 31.3 & 15.2 & 52.5 & 1.1 \\
\hline 2005 & 30.9 & 15.0 & 52.7 & 1.3 \\
\hline 2007 & 36.9 & 11.2 & 51.0 & 0.9 \\
\hline 2009 & 32.8 & 12.3 & 54.0 & 0.8 \\
\hline
\end{tabular}


Table 11. Logistic Regression of Active Pension Contributions by Married Men

\begin{tabular}{|c|c|c|c|c|}
\hline & \multicolumn{2}{|c|}{ Model I } & \multicolumn{2}{|c|}{ Model II } \\
\hline & Coeff. & Std. Error & Coeff. & Std. Error \\
\hline Intercept & -1.55 & .085 & -1.158 & .0763 \\
\hline $\begin{array}{l}\text { Reported to be } \\
\text { required } \\
\text { contribution }\end{array}$ & $18.49 * * *$ & .038 & ------ & ---- \\
\hline Wealth negative & $.155^{*}$ & .081 & $.211 * *$ & .072 \\
\hline $\begin{array}{l}\text { Wealth } \\
\$ 10-50 \mathrm{~K}\end{array}$ & -.053 & .083 & -.020 & .073 \\
\hline $\begin{array}{c}\text { Wealth } \\
\$ 50-\$ 125 \mathrm{~K}\end{array}$ & $.434 * * *$ & .066 & $.495^{* * *}$ & .059 \\
\hline $\begin{array}{c}\text { Wealth } \\
\$ 125-\$ 250 \mathrm{~K}\end{array}$ & $.553^{* * *}$ & .071 & $.586^{* * *}$ & .064 \\
\hline $\begin{array}{l}\text { Wealth } \\
>\$ 250 \mathrm{~K}\end{array}$ & $.381 * * *$ & .078 & $.395^{* * *}$ & .070 \\
\hline Income $(\$ 1,000)$ & $.018^{* * *}$ & .003 & $.017 * * *$ & .002 \\
\hline $\begin{array}{c}\text { Out-of-Pocket } \\
\text { Medical Exp } \\
(\$ 1,000)\end{array}$ & $-.040^{*}$ & .017 & -.020 & .018 \\
\hline Wave 01 & $.219 * * *$ & .074 & $.124 * *$ & .065 \\
\hline Wave 03 & .010 & .075 & -.078 & .066 \\
\hline Wave 05 & -.0394 & .0754 & -.085 & .066 \\
\hline Wave 07 & $.3291 * * *$ & .0722 & $.178^{* * *}$ & .064 \\
\hline Wave 09 & .0917 & .0737 & $-.016^{* *}$ & .065 \\
\hline
\end{tabular}


The pension sequence includes whether participation in the plan is reported to be a condition of employment. This variable is, of course, strongly predictive. The first model estimated includes this covariate. Yet, considering that people have some choice in their employment, being employed may be considered as - in part - a commitment device, thus, who is employed and 'participates' is of interest. In Model II where the variable, 'Required Contribution' is excluded, the impact of the other covariates changes modestly.

One particularly interesting possibility is that of pension contributions as a response to perceived economic uncertainty. As the Great Recession progressed and cast an aura of precarious financial and labor markets, we know that the aggregate national savings rate has risen, and one component of private saving is pension contributions. Yet, in the main, our evidence suggests that there was a change away from making pension contributions toward withdrawing from pensions as the economy transitioned from high levels of activity to recession with declining financial market value. This is reinforced by the strong relation with current family income (from the full calendar year prior to the survey year). As income falls, the likelihood of making pension contributions falls, so more resources are potentially available to support current consumption. Combined with the overall family level withdrawals from existing fund balances, pensions have a role in stabilizing the macro economy, which deserves closer attention. That role may come in conflict with the ability to provide for longer term retirement needs, at least for some families.

In pension contribution Models I and II we see the relationship between income and non-pension net worth and making contributions. Those with higher family income (calendar year 2008) are more likely to make contributions. Net worth has a pattern of a reduced contribution probability for those with the least (positive) net worth - here the excluded groups with net worth of $\$ 0$ - $\$ 9,999$ and $\$ 10,000$ $\$ 49,999$. By comparison, those with negative net worth are more likely to contribute. 
This is consistent with the finding that those with negative net worth are more in the game', participating in financial markets, while those with no assets or very limited assets are a different group - being 'out of the financial game' (Hurst, Luoh and Stafford, 1998).

The families with negative net worth have a financial history, often with business investments, and have been 'in the game'. In the context of the Bayesian learning (Kédzi-Willis, 2011), these families may be the ones with the accumulated financial knowledge needed to take steps to accumulate pension wealth even during adverse financial times. Similarly, for higher levels of net worth, the probability of participation is higher. The variables indicating the survey year show again a relation to overall financial markets. In 2001 and 2007, the level of participation was higher, while in 2003 and 2009 - years following strong downturns in financial markets - we see a lower contribution probability. Flow-of-funds data indicate a shift to smaller pension fund inflows. The question of whether a substantial group of workers took steps to boost their pension contribution remains of interest.

One reason we may expect a pension savings response for some groups is that such a pattern of dispersed holdings of liquid assets by families is observed, 20092011 (Stafford, Chen and Schoeni, 2012), and as shown in the financial market expectations studies (Dominitz and Manski; Hudomiet, Kédzi and Willis; and Hurd and Rohwedder), many hold naïve financial market expectations and there is substantial expectations heterogeneity. Looking at a liquid asset transition table, 20092011, we can see that those families with limited or no liquid assets were likely to persist there or experience even further asset reductions. For those with $\$ 50,000$ or more in liquid assets we see increased holdings. Such a pattern is consistent with both the observed rise in the rate of aggregate private savings and a wide range of models setting out the theory of savings as a response to risk (Sandmo, 1967) as well as asset allocation models (Campbell and Viciera, 2001). 
A question of interest for both liquid assets and for pension contributions is assuming there is an observed pension contribution response - the source of such new inflows. It is possible that the new inflows to liquid assets and perhaps to pensions came from reduced consumption, reallocation from other assets, or both. We see a shift away from home ownership and, with falling home prices a clear decline in net worth in the form of own home. This was both the result of the housing crisis, but likely reflects in part a reassessment of the attractiveness of owneroccupied housing as an investment going forward.

\section{Conclusion}

Overall, the percent of the labor force covered by any pension type fell over the period 2001-2009, with most of the shift occurring in 2001-2003, as indicated by data from the Panel Study of Income Dynamics (PSID). The analysis indicates the factors that lead families to lose or gain DC coverage, to contribute to their private pensions, or to draw money out of private pensions and annuities prior to age 65 . The importance of such discretionary participation and savings responses is accentuated by both the presence of DC pensions, and, presumably, learning that such pensions can be used to stabilize finances prior to retirement.

As the U.S. economy has shifted to greater reliance on defined contribution pension plans, data from 1999-2009 from the PSID indicate that coverage under DC plans has varied from year to year and appears to respond to prevailing macroeconomic conditions and companion changes in financial markets. In the years after financial market declines of 2001-02 and 2008-09, many families took money out of their pensions and, conditional on making a withdrawal, the amounts at the $60^{\text {th }}$ and $80^{\text {th }}$ percentiles were substantially larger. Moreover, during the two recessions the coverage rate for those age 25-65 drops in part from those who are not employed. Married families in which the husband was in the age 58-60 age range exhibit a 
substantially higher percent likelihood of withdrawing funds - a result consistent with the tax code.

Conceptually and empirically there is a higher rate of personal savings in recessions - and one component of saving is pension contributions. However, the flow of funds and microdata indicate that increased pension savings is not a part of this. Yet, theoretically, there could be a subset of pension participants who, in response to perceived economic risk in labor markets, would be likely to take steps to boost their savings as a response and allocate more to liquid assets or pension holdings. Preliminary studies suggest that the savings response by households to recent economic uncertainties, 2009-2011, is greater overall savings and an increase in liquid asset holding, a result consistent with classic predictions of a response to economic turmoil. Overall, pension savings do not appear to be central to this and rather, appear to be a route to stabilizing family consumption. 


\section{References}

Benartzi, Shlomo, 2001, Excessive Extrapolation and the Allocation of 401(K) Accounts to Company Stock, Journal of Finance 56(5), 1747-1764.

Brown, Murray and Dale Heien, "The S-Branch Utility Tree: A Generalization of the Linear Expenditure System," Econometrica, Vol. 40, No. 4, pp. 737-747, July 1972.

Campbell, John Y. and Luis M. Viciera, Strategic Asset Allocation: Portfolio Choice for Long Term Investors, Oxford University Press, 2001.

Chiteji. Ngina S., Elena Gouskova and Frank P. Stafford, "Pension Participation: Do Parents Transmit Time Preference?" Journal of Family and Economic Issues, Vol. 31; p.138-150, 2010.

Chiteji, Ngina S, Elena Gouskova and Frank P. Stafford, "Financial Marketplace Participation and Pension Holdings Over the Life Course," p. 191-198 in Wealth Accumulation and Communities of Color in the United States, 2006.

Choi, James J., David Laibson, Brigitte C. Madrian and Andrew Metrick, "Employees' Investment Decisions About Company Stock,” Working Paper 10228, National Bureau of Economic Research, Cambridge, MA. January 2004.

Dominitz, Jeff, and Charles F. Manski, "Measuring and Interpreting Expectations of Equity Returns,"Journal of Applied Econometrics, Vol. 26, p 352-370, 2011.

Dushi, Irena, and Howard M. Iams. 2010. The Impact of Response Error on Participation Rates and Contributions to Defined Contribution Pension Plans. Social Security Bulletin 70(1): 45-60.

Federal Reserve Board, Flow of Funds Accounts of the United States, Federal Reserve Statistical Release, Table F.225.i, June 7, 2012.

Gustman, Alan L. and Thomas L. Steinmeier, "What People Don't Know About Their Pensions and Social Security: An Analysis Using Linked Data from the Health and Retirement Study," Working Paper 7368, National Bureau of Economic Research, September 1999. 
Heiland, Frank W. and Zhe Li, "Changes in Labor Force Participation of Older Americans and Their Pension Structures: A Policy Perspective," Center for Retirement Research at Boston College, Working Paper 2012-18, August 2012.

Hudomiet, Péter, Gábor Kédzi and Robert J. Willis, "Stock Market Crash and Expectations of American Households,"-Journal of Applied Econometrics, Vol. 26, p. 393-415, 2011.

Hurd, Michael, Lee Lillard and Constantijn Panis, "An Analysis of the Choice to Cash Out Pension Rights at Job Change or Retirement" Working paper, RAND, October, 1998.

Hurd, Michael, and Suzanne Rohwedder, "Stock Price Expectations and Stock Trading," Working Paper 17973, National Bureau of Economic Research, April, 2012.

Hurst, Erik, Ming-Ching Luoh and Frank P. Stafford, "Wealth Dynamics of American Families, 1984-1994,” rookings Papers on Economic Activity, 1998: 1, p. 267-337.

Juster, F. Thomas, Joseph Lupton, James P. Smith and Frank P. Stafford, "The Decline in Household Savings and the Wealth Effect," Review of Economics and Statistics, 2006.

Kédzi, Gabor and Robert Willis, "Household Stock Market Beliefs and Learning," Working Paper 17614, National Bureau of Economic Research, November, 2011.

Lu, Timothy and Olivia S. Mitchell, "Borrowing from Yourself: The Determinants of 401(k) Loan Patterns," Working Paper 2010-11, Michigan Retirement Research Center, September, 2010.

Klein, Lawrence R. and H. Rubin, "A Constant Utility Index of the Cost of Living," The Review of Economic Studies, Vol.15, p.84-87, 1948.

Munnell, Alicia H. and Laura Quinby, "Why Did Some Employers Suspend Their 401(k) Match?” Policy Brief, Number 10-2, Boston College, Center for Retirement Research, February, 2010.

Munnell, Alicia H., “401(k) Plans in 2010: An Update from the SCF," Report, Center for Retirement Research, Boston College, July 2012, Number 12-13, p.1-13. 
Poterba, James M., Steven Venti and David A. Wise, "How Retirement Saving Programs Increase Saving," The Journal of Economic Perspectives, Vol. 10, No. 4, (Autumn, 1996) p.91-112.

Sandmo, Agnar, "The Effect of Uncertainty on Savings Decisions," Review of Economic Studies, Vol. 37, No. 3, p.353-360.

Solon, Gary, Robert Barsky and Jonathan A. Parker, "Measuring the Cyclicality of Real Wages: How Important is Composition Bias?" Quarterly Journal of Economics, February, 1994, Vol. 109(1), p. 1-25.

Stafford, Frank P., and Elena Gouskova, "Mortgage Contract Decisions and Mortgage Distress: Family and Financial Life Cycle Factors," Working Paper 2012-225, Michigan Retirement Research Center, September 2010.

Stafford, Frank P., Erik Hurst, and Bing Chen, "Diminishing Margins: Housing Market Declines and Family Financial Responses," Working Paper 2012-276, Michigan Retirement Research Center, December 2012. , Bing Chen and Robert Schoeni, "Mortgage Distress and Financial Liquidity: How U.S. Families are Handling Savings, Mortgages and Other Debts," Research Note, Institute for Social Research, May, 2012.

Teplin, Albert, "The U.S. Flow of Funds Accounts and Their Uses," Federal Reserve Bulletin, July 2001, p.431-441. 